\title{
Morphological characteristics and motor skills of young students with different levels of engagement in physical activities
Características morfológicas y habilidades motrices de estudiantes jóvenes con diferentes niveles de participación en actividad física

\author{
*Maja Batez, *Branko Krsmanovic, *Milena Mikalacki, *Nebojsa Cokorilo, *Marijana Simic, **Pedro Jesús Ruiz-Montero \\ *University of Novi Sad (Serbia), **Universidad Internacional de La Rioja (Spain)
}

\begin{abstract}
The overall orientation of the research problem is focused on the physical activity level of the participants from the aspect of different intensities of motor engagement and their impact on morphological characteristics and motor skills with an intention of determining whether there are statistically significant differences between groups. In a sample of 103 students, aged between 18 and 20 years (18.9 \pm 0.4 ), the female students were divided into three subsamples according to the level of physical activity: highly active, active and inactive. The study which was conducted had a transversal character. The data obtained in the survey were analysed using the univariate (ANOVA) and multivariate (MANOVA) statistical methods. The motor skills mere monitored by the use of the Eurofit Test Battery (wide-angle seated forward bend, standing long jump, pull-up endurance, $10 \mathrm{x}$ $5 \mathrm{~m}$ shuttle run and endurance shuttle run- beep test). The following morphological characteristics were considered: height, weight, body mass index, percentage of muscular mass and fat mass, as well as waist circumference. The obtained results indicate the existence of statistically significant differences between the \% body muscle mass' groups $(\mathrm{p}<0.05)$ and motor skills parameters (sit and reach, $\mathrm{p}<0.01$; standing broad jump, bent arm hang, $10 \times 5 m$ shuttlerun, beep test, $\mathrm{p}<0.001$ ) of participants according to physical activity level. In conclusion, participants with a high level of physical activities have higher average values than the participants with light level of physical activities when considering the variables for assessing pliability, strength and agility.
\end{abstract}

Keywords: Physical test, physical activity, motor skills, young students, body composition.

Resumen. La orientación general del problema de investigación se centra en el nivel de actividad física de las participantes desde el aspecto de diferentes intensidades de compromiso motor y su impacto en las características morfológicas y habilidades motrices con la intención de determinar si existen diferencias estadísticamente significativas entre los grupos. En una muestra de 103 alumnas, con edades comprendidas entre los 18 y 20 años (18,9 \pm 0,4), las estudiantes fueron divididas en tres grupos de acuerdo con el nivel de actividad física de cada uno: muy activas, activas e inactivas. El estudio llevado a cabo tuvo un carácter transversal. Los datos obtenidos mediante cuestionarios fueron analizados utilizando un análisis de la varianza (ANOVA) y un análisis multivariante de la varianza (MANOVA). Las habilidades fueron controladas mediante la batería Eurofit y para las características morfológicas, se midió la altura, peso, índice de masa corporal, porcentaje de masa muscular, masa grasa y la circunferencia de la cintura. Los resultados obtenidos indican la existencia de diferencias entre los grupos estudiados respecto al \% de masa muscular (p <0.05) y las habilidades motrices (flexibilidadinclinación hacia adelante, $\mathrm{p}<0.01$; salto de longitud a pie, fuerza resistencia mediante flexión de brazos, 10 x 5 m carrera de ida y vuelta y Beep Test, p <0.001) de los participantes según el nivel de actividad física. En conclusión, las participantes con alto nivel de actividad física tienen mayores valores de habilidad motriz que las participantes que el resto en función de las variables flexibilidad, capacidad aeróbica, fuerza y agilidad.

Palabras claves: Test físicos, actividad física, habilidades motrices, estudiantes jóvenes, composición corporal.

\section{Introduction}

A great number of studies analysing this issue have shown that physically active young adults are less exposed to a risk of numerous cardiovascular diseases, diabetes type 2, osteoporosis, some forms of malign tumours and many other diseases because of the effects of physical exercise (Pano, 2014). Moreover, a regular physical activity contributes to a healthy body composition in adolescents and young adults. This knowledge has gained in popularity, since modern lifestyle entails a series of risks caused by a reduced body engagement (Howie, Campbell \& Straker, 2016; WHO, 2015).

With regards to young overweight people, physical exercises may improve the body composition levels by reducing a total amount of fat in the body, as well as the visceral fat. Researches demonstrate that fat can be reduced by having a regular physical activity of moderate to high intensity involving three to five trainings a week, which would last 45 to 150 minutes (ACSM, 2013). In addition, it is important to watch a poor diet and increase of sedentary activities (Finlayson, Cecil, Higgs, Hill \& Hetherington, 2012). Moreover, nowdays the fall of physical activity in our society is marked by means of communications development and communications technology (Urrutia, Irazusta, Belardi, González \& Arruza, 2013). In most of countries it's noticeable that the level of physical activity is decreasing with all ages groups. Moreover, researchs show that $23 \%$ of adults and $81 \%$ of adolescents are insufficiently active in relation to expected standard according to age, which represents big problem (WHO, 2015).

The data obtained by the researches on health condition of the

Fecha recepción: 08-08-16. Fecha de aceptación: 14-04-17

Pedro Jesús Ruiz-Montero

pedrojesus.ruiz@unir.net population in Serbia (National Health Survey of Serbia, 2006) testify that more than two thirds of adult population in Serbia is physically inactive (67.7\%). In adittion, Bozic et al.'s research (2016) comprised a survey of high school students from Serbia where it was indicated a inadequate level of health and fitness (60\% male students and $87 \%$ female students were below recommended standards) and level of daily recommended volume of physical activity (56\% male students and even $75 \%$ female students were below standards). In the other hand, the obesity is an excess of body fat that increases considerably the prevalence of several illness (Amarya, Singh \& Sabharwal, 2014). Fat mass (FM) increases and fat free mass (FFM) decreases after 20-years old (Colado, García-Masso, Rogers, Tella Benavent \& Dantas, 2012). Overweight and obesity growing problem are one of the biggest problems of our time due to 1.9 billion people aged over 18 have problems (WHO, 2015). Therefore, it is imporat to practise regular physical activity as the healthiest way of obtaining better health in general (Pinto, Franzini, Pires \& Moya, 2017). Thus, the presence of physical activity in teenager and young people's life determines the person's healthy development (Oviedo, Sánchez et al., 2013) as well as a school achievements (Correa-Burrows, Burrows, Ibaceta, Orellana, \& Ivanovic, 2014).

Motor abilities are hidden, latent human abilities that are manifesting in motion. Every human has them, just on the different level. Level of manifesting motor abilities depends of several factors like genetics, gender, age, and training. Moreover, the basic motor abilities are manifesting and expressing only and exclusively through out motor activity, and their level depends from quality and quantity of that motor activity.

Based on the given facts, this study is focused on physical activities of the participants (young female students) with a special attention devoted to the risk assessment of various intensities of motor engagement so as to realize whether and to what extent a physical activity contributes 
to the improvement of the morphological characteristics and motor skills of high school female students.

\section{Materials and Methods}

The research of the assessment of the morphological characteristics and motor skills of high school girls has a transversal character and uses the experimental research method.

\section{Participants}

The total sample of examinees included in this research was composed of a population consisting of 103 female students attending the vocational training centre «Svetozar Miletic» in Novi Sad, aged between 18 and 20 years $(18.9 \pm 0.4)$. The inclusion criteria were i) not to be diagnosed with an acute or terminal illness, ii) to be students of the sameeducation centre. Male students were excluded because theirnumber would not be representative of the total. Participants were informed of the purpose of the present study.

\section{Measurements}

For the purpose of determining the girls' morphological status and level of motor skills, with the aim of monitoring and comparing the obtained results, were estimated the morphological characteristics and motor dimensions concerning the girls covered by the sample, were estimated based on which an insight into the following was obtained: longitudinal skeletal dimensionality, volume and body mass, body composition and motor skills. In order to determine the level of physical activity, questions in a socio-demographic questionnaire (frequency, duration and type of physical activity) were used. In addition, the estimation of physical activity was taken from the table produced by metabolic equivalents(METs): inactive, active and highly active(Hofman, 2006). Then, the different groups were made on the basis of METs and the duration of activities and classified according to the table: inactive (less than 150 minutes of physical activity on a weekly basis), active (150 to 300 minutes of physical activity on a weekly basis) and highly active (over 300 minutes of physical activity on a weekly basis) (Heyward, 2010; Ainsworth et al., 2011).

The body mass index (BMI), \% body fat mass and body muscular mass were measured using the bioelectrical impedance analysis with a Tanita SC 330s. The waist circumference was measured by the anthropometric measuring tape (Holden model). Motor skills were monitored by using the Eurofit Battery (Moravec, Kampmiller, \& Sedlácek, 1996) composed of the following tests: sit and reach, standing broad jump, the bent arm hang test, $10 \times 5 \mathrm{~m}$ shuttle run and 20 multistage fitness test (Beep Test).

\section{Procedure}

Data was collected once. The interventional program had a 70\% attendance rate during this period. Participants were recruited from the vocational institution (economic and tourism orientation) located in the Republic of Serbia, city of Novi Sad. This institution has 2600 students and more than 70 departments, representing one of the largest schools for human resources service sector in Serbia. The participants of the present study were mainly female. The reason for that is the fact that the students in this particular studying profile are mostly females, with males being in the minority. The male students were also tested, but they are not included in the final intervention because of the lack of participants.

Motor skills tests, morphological characteristics and estimation of physical activity were conducted during the same week to all participants. We need two sessions to complete the battery and evaluations. We have carried the measuring in a covered room with temperature ranging between $17-21^{\circ} \mathrm{C}$. Before the tests, participants conducted a formal and non-exhausted warm.

This study was approved by Ethical Committee of the University of Novi Sad and Provincial Secretariat for Science and Technological Development in Novi Sad (Project nº 114-451-2337/2011-01).

\section{Statistical analyses}

The normal distribution of the data was studied using the Kolmogorov-Smirnov test. All the variables studied presented a normal distribution.The collected data processing included the use of adequate statistical methods for calculating central and dispersion parameters: arithmetic mean (Am), minimum value (Min), maximum value (Max) and variation coefficient (VC\%). To determine the significance of differences between the systems, the applied anthropometric and motor skills variables were tested by means of the multivariate analysis of variance (MANOVA). In adittion, the univariate analysis of variance (ANOVA) was calculated to assess the differences between the individual variables of anthropometric characteristics and motor skills variables. Finally, the discrimination of the groups regarding the anthropometric characteristics and motor skills variables was performed by the linear discriminant function analysis. The data were analyzed using the SPSS statistical program (SPSS for Windows 19.0, Inc., Chicago, Illinois, USA). For all analyses, the significance was accepted at $\mathrm{P}<0.05$.

\section{Results}

After reviewing and considering the results' arithmetic means (Table 1), it has been observed that the results referring to the growth and development of the participants are within the expected scope and actually possible values regarding the examined age, which is also confirmed by the average values of the results obtained from the previous researches conducted by Rakic et al. (2010). The analysis of theminimum and maximum values of the morphological characteristics of the female participants' engagement in vigorous (highly active), moderate (active) and light level (inactive) physical activities indicates the existence of individual differences in almost all variables.

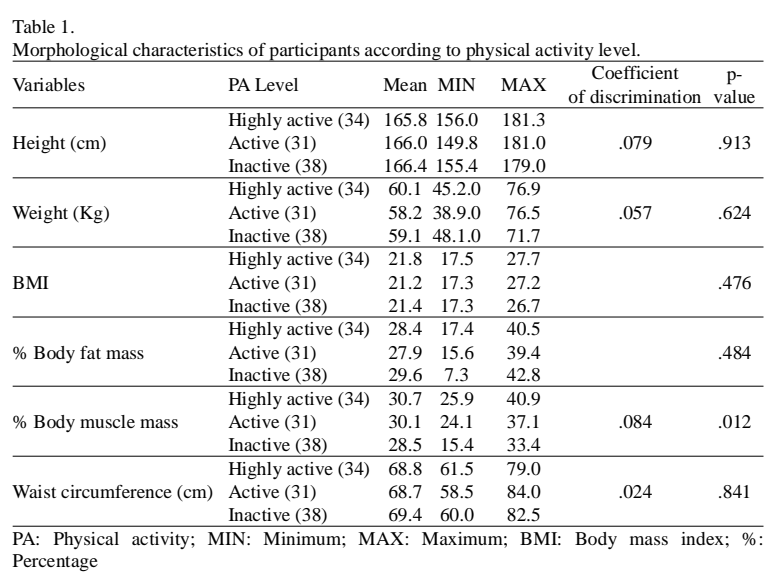

The participants with a vigorous and moderate (highly active group) and moderate level (active group) of physical activity are on average taller than the girls with a lighter level (inactive group) of physical activity.

Based on the discrimination degree, the characteristics of each level of the physical activity of the participants can be derived. The coefficient of discrimination by the analysis of variance shows different levels of physical activity in relation to the morphological characteristics, with the greatest difference occurring in the variables for assessing the body muscle mass (.084), which is also indicated by significant differences between the groups within one variable $(\mathrm{p}<.012)$.

By examining the average mean of the morphological characteristics of the participants with different physical activity intensities, it can be noticed that the highest arithmetic mean of the variables for assessing the body muscle mass are found in the participants with a high level of physical activity, when compared to the participants with a moderate level of physical activity. Finally, the lowest arithmetic mean is found in the participants with a low level of physical activity.

Since the average results of the morphological characteristics of the participants in three levels of motor engagements were different, it was 
important to examine whether the three groups were statistically significantly different in terms of the morphological variables. The values of the results of the multivariate variance analysis indicate that, in the system of six applied morphological variables, there are no statistically significant differences between the intensities of the physical activity of the participants $(\mathrm{F}=.000 ; \mathrm{p}=1.000)$.

Based on the table 2, participants with a high level of physical activity showed greater arithmetic mean values compared to the participants with a light level of physical activities in terms of variables for assessing flexibility, agility and endurance, while the participants with an active level of physical activity had greater values compared to those with a light level of physical activity in terms of variables for assessing explosive strength of low extremities muscles.

\begin{tabular}{|c|c|c|c|c|c|}
\hline Variables & PA Level & Mean MIN & MAX & $\begin{array}{c}\text { Coefficient } \\
\text { of discrimination }\end{array}$ & p-value \\
\hline & Highly active (34) & 609.12430 .0 & 770.0 & .010 & .007 \\
\hline \multirow[t]{3}{*}{ Sit and reach } & Active (31) & 600.32390 .0 & 800.0 & & \\
\hline & Inactive (38) & 545.79320 .0 & 710.0 & & \\
\hline & Highly active (34) & 171.74149 .0 & 200.0 & .046 & .000 \\
\hline \multirow[t]{3}{*}{ Standing broad jump } & Active (31) & 174.23143 .0 & 216.0 & & \\
\hline & Inactive (38) & 150.6374 .0 & 202.0 & & \\
\hline & Highly active (34) & 307.7181 .0 & 754.0 & .000 & .000 \\
\hline \multirow[t]{3}{*}{ Bent arm hang } & Active (31) & 275.7484 .0 & 727.0 & & \\
\hline & Inactive (38) & 114.2410 .0 & 411.0 & & \\
\hline & Highly active (34) & 197.35170 .0 & 219.0 & .073 & .000 \\
\hline \multirow[t]{2}{*}{ 10x5m shuttlerun } & Active (31) & 203.55184 .0 & 231.0 & & \\
\hline & Inactive (38) & 215.79185 .0 & 239.0 & & \\
\hline \multirow{3}{*}{ Beep Test } & Highly active (34) & 665.29320 .0 & 1300.0 & .037 & .000 \\
\hline & Active (31) & 521.29160 .0 & 880.0 & & \\
\hline & Inactive (38) & 362.11100 .0 & 680.0 & & \\
\hline
\end{tabular}

By analysing the arithmetic mean of the results, it can be noticed that the differences in most variables indicate a greater approval of the participants with a high active level of physical activities in comparison to those with a light level of physical activities. In the variable for assessing agility (10x5 shuttle run), numerically speaking, the participants with a high active level of physical activity achieved lower results than those with a light level of physical activity, due to the fact that higher achievements were valued with lower scores within this test (to perform the task in the shortest possible period of time).

According to the central and dispersal parameters of the motor skills, numerical differences between certain groups in the examined variables were noticed; therefore, it was necessary to check whether those differences were statistically significant in the motor variables system which was used. Based on the results of the multivariate analysis of variance for five observed motor engagement characteristics, it can be concluded that there are statistically significant differences between different physical activities the participants engage in $(\mathrm{F}=6.999$; $\mathrm{p}<$ $.001)$.

\section{Discussion}

The main aim of the present study was to assess the different intensities of motor engagement so as to realize whether and to what extent physical activity contributes to the improvement of the morphological characteristics and motor skills of high school female students.

With regards to the standard development of female sex within the examined age, it can be observed that participants with a lighter level of physical activity and large circular measures had more body fat tissue when compared to the group of participants engaged in a vigorous and moderate level physical activity. Summing up the results od a longitudinaly study Ramires, Dumith \& Gonçalves (2015) come to smilar conclusions. It is assumed that the body structure and motor skills were significant factors for the participants' increased engagement in sport activities (Bielemann et al., 2013). Several factors are related with level of physical activity, such as gender, age, medical condition and motivation. All listed factors determine and have direct influence on level of performing any physical activity (Bauman et al., 2012).

The greatest difference in the morphological characteristics occurs in the muscle mass, followed by body height and, finally, body mass. It is assumed that the observed differences between the groups are caused by the physical development of the participants, their motor engagement, as well as the appropriate nutrition which is essential for building the muscle mass (Moreno et al., 2014). On the other hand, bad nutrition can cause energy imbalance or can increase the risk of overweight and obesity (Gupta, Goel, Shah \& Misra, 2012). Bad and poor nutrition also have several negative effects, which one of them is low achievement in school (Correa-Burrows et al., 2015). It is considered that adolescence period is crucial in obtaining healthy pattern of behavior in which the physical activity and nutrition are key parameters (Bo•iæ et al., 2016). The nutrition of students should be varied with optimal intake of fruits, vegetables, cereals, meat and milk products. Beside that its desirable reducing level of soda drinks, drinks with caffeine, fried and fast food which are often available to children in school canteens. Adequatenutrition and engagement in certain physical activities lead to fat burning and building muscle mass. Females with optimal body weight enjoy more in physical activities and perform it more often then females with overweight and obesity problem (Seabra et al., 2013). It can be said that this result is very much expected with regard to different intensities of physical activities. Therefore, physical exercise is recommended as an intervention strategy to promote the optimal bone density during youth (Pate, Flynn \& Dowda, 2016) and to lower the speed of body mass loss in middle-aged and elderly adults (Martyn-St James \& Carroll, 2008).

The results of several studies show that young female adults are less physically active than young male adults (Telford, Telford, Olive, Cochrane, \& Davey), as well as that the degree of participants' activity is sharply reduced in adolescence (Lowry, Lee, Fulton, Demissie \& Kann, 2013). Asare and Danquah (2015) suggest that the association between adolescent and adult physical activity is dependent, at least in part, on the type of physical activity engaged in during adolescence. It is obvious that a certain model and type of participants' body activities during adolescence is not accepted enough, and it continues in subsequent periods. Physical activity, with time, is becoming part of daily habit. So it's necessary that activities that are marked as positive for specific target group encourage on a regular basis. Otherwise, physical inactivity will happen which will result in numerous health problems. With children of adolescent age is necessary that physical activity be individualized or adapted according with interests or needs of children of that age.

By comparing the morphological and motor indicators in the participants with different levels of physical activities, significant positive differences are noticeable in favour of the participants with a high active or active level of physical activities in comparison to the girls characterised as having a light active level of physical activities, i.e. who are not engaged in any kind of physical activity or such engagement is below an average one. Physical activity has direct influence on health condition of females, which has been shown in this research. The last sentences coincide with the conclusion of Shiroma's study (2017) where it is shown an improvement of several physical fitness and lower risk of Type 2 diabetes in females participants of physical exercises program. On the other hand, females that are not physically active had $17 \%$ higher risk of cardiovascular disease. According to Diamond (2016), more than half of adults and one-third of high school age children, do not participating sufficiently in recommended levels of physical activity.

Compared to inactive individuals, physically active young people have a higher level of cardiorespiratory form and stronger muscles. These individuals also have a lower body fat content. Young people under 18 years can significantly benefit from being engaged in physical activities of high or moderate level in periods that last up to 60 minutes (1h) or more each day (Luque et al., 2010). Adults aged 18-64 should do at least 150 minutes of moderately intense physical activity each week, or at least 75 minutes of vigorous activity throughout the week, or an equivalent combination of moderate and vigorous activity. In order to be beneficial for cardio-respiratory health, all activity should be performed 
in bouts of at least 10 minutes duration (ACSM, 2017).

Moreover, overweight and obesity occur as the result of a disbalance between the energy consumption and energy intake and it is defined as the existence of a mass tissue surplus in the organism (Bukara-Radujkovic \& Zdravkovic, 2009). In children and young adults, the body fat content changes with growing. With regards to 18-year-olds, such content reaches $18 \%$ and, regarding the participants, it is $20-25 \%$; in adults with the ideal body mass, it reaches $20 \%$. Furthermore, the average body mass index (BMI) among youth has increased from 21.3 to 24.1 (Diamond, 2016). Several authors state that an intensive physical activity can reduce fat content in the organism and increase the muscular tissue mass. Body mass, as well as the amount of body fat, are physiologically controlled (Foong et al., 2014).

Young people who are active on an everyday basis have a better chance of becoming healthy adults. A positive development of young people facilitates the adoption of healthy behavioural patterns and enables creating healthy and productive future generations (RuizMontero et al., 2015). It is important to encourage young people to engage in various and pleasant physical activities suitable for their age. For inactive people it is recommended that, when they start with performing some physical activity, that activity has to be dosed. Physical activity should be part of daily routine, and after some time it should be increased in terms of intensity and time interval. Besides, government has obligation and responsibility towards individuals to provide the opportunity for participating in sport, and through sport increase their activity.

\section{Conclusions}

In conclusion, the average values of morphological characteristic on female students with lower level of physical activity and with circular larger dimensions show more body fat than female students that are physically active. Female students with higher level of physical activity report larger average values than female students with lower level of physical activity, considering variables assessing flexibility, endurance and agility. In elementary schools physical activity should be promoted with proper nutrition, so that habits could be adopted and transferred to adolescent and adult period. It is necessary for children to understand that physical activity such as walking, riding the bicycle, roller-skating and daily school physical exercise must increase to develop motor skills and improve own morphological characteristics. One limitation of the present study should be considered. The sample was composed of female participants only; it would be necessary though to do a research including male participants as well.

\section{Acknowledgments}

Present study was funded by the Provincial Secretariat for Science and Technological Development in Novi Sad, and was entitled. «Impact of Physical Activity on the Risk Factors of the Working Population» (number: 114-451-2337/2011-01).

The authors express their sincere gratitude to all female students who participated in this study and apologize for any inconvenience it may have caused them.

\section{Declaration of Interest}

The authors declare no conflict of interests.

\section{References}

ACSM's Guidelines for Exercise Testing and Prescription. 10th ed. Philadelphia: Lippincott; 2017.

Ainsworth, B.E., Haskell, W.L., Herrmann, S.D., Meckes, N. Bassett, J.R., Tudor-Locke, C. et al. (2011). Compendium of Physical Activities: a second update of codes and MET values. Medicine and Science in Sports and Exercise, 43(8), 1575-1581.
Amarya, S., Singh, K. \& Sabharwal, M. (2014). Health consequences of obesity in the elderly. J Clin Gerontology \& Geriatrics, 5(3):63-67. American College of Sport Medicine (ACSM) (2013). Guidelines for Exercise testing and Prescription. $9^{\text {th }}$ ed. Philadelphia (PA):Lippincott, Wilkins, and Williams.

Asare, M. \& Danquah, S.A. (2015). The relationship between physical activity, sedentary behaviour and mental health in Ghanaian adolescents. Child and Adolescents Psychiatry and Mental Health, 9:11.

Bauman, A. E., Reis, R. S., Sallis, J. F., Wells, J. C., Loos, R. J., Martin, B. W., \& Lancet Physical Activity Series Working Group. (2012). Correlates of physical activity: why are some people physically active and others not?. The lancet, 380(9838), 258-271.

Bielemann, R.M., Martinez-Mesa, J., \& Gigante, D.P. (2013). Physical activity during life course and bone mass: a systematic review of methods and findings from cohort studies with young adults. BMC MusculoskeletDisord, 14, 77.

Bo•iæ, P., Ostojiæ, S., Berjan-Baèvareviæ, B., Radisavljeviæ-Janiæ, S., Pa•in, N., Milovanoviæ, I., Mirkov, D. \& Èapriæ, G. (2016) Vodiè za fizièku aktivnost $i$ ishranu mladih. Fizièka aktivnost $i$ ishrana uèenika srednjih škola. Beograd: Udru•enje za sport i medicinu sporta

Bukara-Radujkoviæ, G, \& Zdravkoviæ, D. (2009). Fizièka aktivnost znaèajan faktor u spreèavanju gojaznosti u deèijem uzrastu. Medicinski pregled, (3-4), 107-113.

Cash, T.F., Novy, P.L., \& Grant, J.R. (2004). Why do women exercise? Factor analisys and further validation of the reasons for the exercise inventory. Perceptual and motor skills, 78, 539-544.

Colado, J.C., Garcia-Masso, X., Rogers, M.E., Tella, V., Benavent, J., \& Dantas, E.H.(2012). Effects of Aquatic and Dry Land Resistance Training Devices on Body Composition and Physical Capacity in Postmenopausal Women. Journal of Human Kinetics, 32, 185195.

Correa-Burrows, P., Burrows, R., Orellana, Y., \& Ivanovic, D. (2015). The relationship between unhealthy snacking at school and academic outcomes: a population study in Chilean schoolchildren. Public health nutrition, 18(11), 2022-2030.

Diamond, A. B. (2016). The cognitive benefits of exercise in youth. Current sports medicine reports, 14(4), 320-326.

Dishman, R.K., Heath, G.W., \& Min, L.I. (2012). Measurement and Surveillance of Physical Activity and Fitness. In Physical Activity Epidemiology ( $2^{\text {th }}$ ed.) (pp. 38-70). Champaign, IL: Human Kinetics.

Foong, Y.C., Aitken, D., Winzenberg, T., Otahal, P., Scott, D., \& Jones, G. (2014). The association between physical activity and reduced body fat lessens with age-Results from a cross-sectional study in community dwelling older adults. Experimental Gerontology, 55, 107-112.

Finlayson G., Cecil J., Higgs S., Hill A., \& Hetherington M. (2012). Susceptibility to weight gain. Eating behaviour traits and physical activity as predictors of weight gain during the first year of university. Appetite, 58, 1091-1098.

Hofman, J. (2006). Norms for fitness, performance and health. Champaign (IL): Human Kinetics.

Howie, E. K., Campbell,A. C., \& Straker, L. M. (2016). An active video game intervention does not improve physical activity and sedentary time of children at risk for developmental coordination disorder: a crossover randomized trial. Child: care, health and development, 42(2), 253-260.

Gupta, N., Goel, K., Shah, P., \& Misra, A. (2012). Childhood Obesity in Developing Countries: Epidemiology, Determinants, and Prevention. Endocrine Reviews, 33(1), 48-70.

Karlsson, M., Magnusson, H., Karlsson, C., \& Seeman, E. (2001). The duration of exercise as a regulator of bone mass. Bone, 28, 128-132.

Lowry, R., Lee, S.M., Fulton, J.E., Demissie, Z \& Kann, L. (2013). Obesity and other correlates of physical activity and sedentary behaviors among US high school students. Journal of obesity, 2013: 276318. 
Luque, G.T., García-Martos, M., Gutiérrez, C.V., \& Vallejo, N.G. (2010). Papel del ejercicio físico en la prevención y tratamiento de la obesidad en adultos. Retos Nuevas Tendencias en Educación Física, Deporte y Recreación, 18, 47-51.

Martyn-ST James, M., \& Carroll, S. (2008). Meta-analysis of walking for preservation of bonemineral density in postmenopausal women. Bone, 43, 521-531.

Moravec, R., Kampmiller, T., \& Sedlácek, J. (1996). Eurofit, Slovenska vedeckaspoloènost pre telesni vihovu a šport. Bratislava: University of Presov.

Moreno, L. A., Gottrand, F., Huybrechts, I., Ruiz, J. R., GonzálezGross, M., DeHenauw, S., \& HELENA Study Group. (2014). Nutrition and lifestyle in european adolescents: the HELENA (Healthy Lifestyle in Europe by Nutrition in Adolescence) study. Advances in Nutrition: An International Review Journal, 5(5), 615623.

National Healt Survey of Serbia. Republic of Serbia: Ministry of health, 2006. http://www.batut.org.rs

Oviedo, G., Sánchez, J., Castro, R., Calvo, M., Sevilla, J.C., Iglesias, A...Guerra, M. (2013). Niveles de actividad física en población adolescente: estudio de caso. Retos. Nuevas tendencias en Educación Física, Deporte y Recreación, 23, 43-47.

Pano, G. (2014). Physical activity benefits for Alzheimer's disease patients (A Review). Journal of Human Sport \& Exercise, 9(1), 319-325.

Pate, R. R., Flynn, J. I., \& Dowda, M. (2016). Policies for promotion of physical activity and prevention of obesity in adolescence. Journal of Exercise Science \& Fitness, 14(2), 47-53.

Pinto, D., Franzini, P.C., Pires, R., \& Moya, J.M. (2017). Anthropometry and Physical Fitness of Latin American Adolescents. Retos. Nuevas tendencias en Educación Física, Deporte y Recreación, 31, 264-270.

Rakiæ, R., Bo॰iæ-Krstiæ, V.I., \& Pavlica, T. (2010). Age changes in height, weight and nutritional condition in adolescents from Novi Sad. ActaMorphologica et Antropologica,15, 217-219.
Ramires, V. V., Dumith, S. C., \& Gonçalves, H. (2015). Longitudinal association between physical activity and body fat during adolescence: a systematic review. Journal of Physical Activity and Health, 12(9), 1344-1358.

Ross, W.D., Marfell-Jones, M.J., Kinanthropometry. (1991). In J.D. Mac Dougall; H.A. Wenger \& H.J. Green (Eds). Physiological testing of the high performance athlete. Champaign, IL: Human Kinetics.

Ruiz-Montero, P.J., Castillo-Rodriguez, A., Mikalacki, M., \& Delgado-Fernández, M. (2015). Physical fitness comparison and quality of life between Spanish and Serbian elderly women through a physical fitness program. Collegium Antropologicum, 39(2), 411417.

Seabra, A., Mendonça, D., Maia, J., Welk, G., Brustad, R., Fonseca, A. M., \& Seabra, A. F. (2013). Gender, weight status and socioeconomic differences in psychosocial correlates of physical activity in schoolchildren. Journal of Science and Medicine in Sport, 16(4), 320-326.

Shiroma, E. J., Cook, N. R., Manson, J. E., Moorthy, M. V., Buring, J. E., Rimm, E. B., \& Lee, I. M. (2017). Strength Training and the Risk of Type 2 Diabetes and Cardiovascular Disease. Medicine and science in sports and exercise. 49(1), 40-46

Telford, R. M., Telford, R. D., Olive, L. S., Cochrane, T., \& Davey, R. (2016). Why Are Girls Less Physically Active than Boys? Findings from the LOOK Longitudinal Study. PLoS ONE, 11(3), e0150041.

Urrutia, S., Irazusta, S. Belardi, A., González, O. \& Arruza, J.A. (2013). Relación entre el índice de masa corporal y la competencia percibida en adolescentes de la Educación Secundaria Obligatoria. Retos. Nuevas tendencias en Educación Física, Deporte y Recreación, 24, 2426.

World Health Organization (WHO) (2015) . Obesity and overweight. Available from: http://www.who.int/mediacentre/factsheets/fs311/ en/

World Health Organisation (WHO) (2000). Obesity: preventing and managing the global epidemic (No. 894). WHO: Geneva.

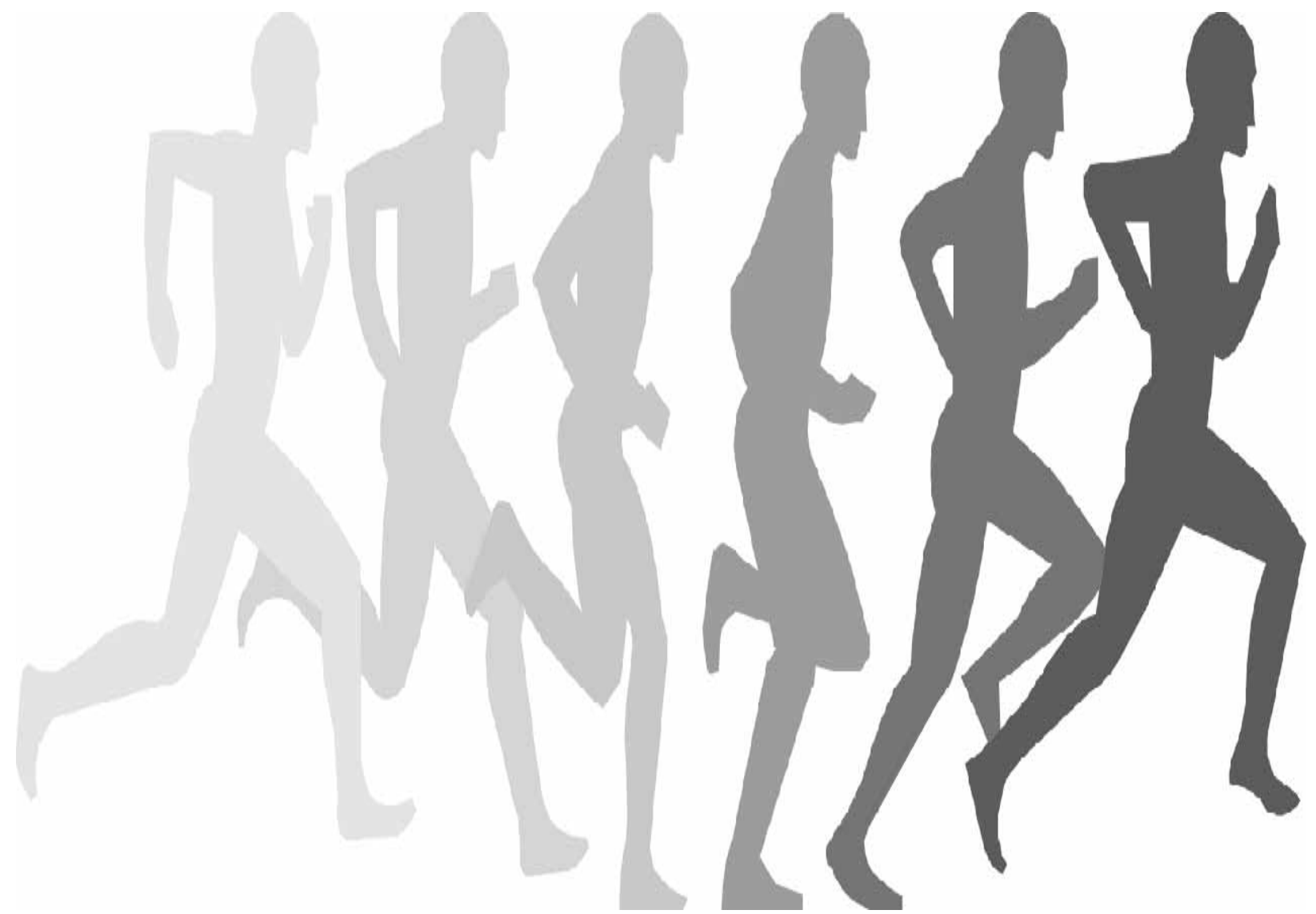

